\title{
DESIGN
}

DOI https://doi.org/10.30525/978-9934-26-004-9-99

\section{РОЗВИТОК ОБРАЗНОГО МИСЛЕННЯ У ДИЗАЙНЕРІВ НА ПРАКТИЧНИХ ЗАНЯТТЯХ 3 «КОЛЬОРОЗНАВСТВА»}

\author{
Блінова I. O. \\ викладач, голова комісї дизайну інтер 'єру \\ Фахового коледжу мистецтв та дизайну \\ Київського начіонального університету технологій та дизайну \\ м. Київ, Україна
}

Предмет «Кольорознавство» $\epsilon$ обов'язковим у процесі фахової підготовки дизайнерів. На даний момент ця дисципліна містить великий обсяг знань i теоретичних узагальнень, які дають змогу грунтовно вивчати предмет і розвивати відчуття гармонії кольору, яке так необхідне дизайнерам у їхній повсякденній роботі.

Але завжди існує проблема поверхового та нестійкого засвоєння студентами необхідної теоретичної бази та застосування iї прикладному аспекті. Стандартні практичні вправи лише ілюструють теоретичний матеріал, а навчальні програми майже не передбачають експериментальних, пошукових завдань, що мають розвивати прикладні навички на основі творчого підходу. «Складно переоцінити важливість підготовки майбутніх дизайнерів у питаннях, що стосуються знання основ кольорової гармонії не лише при виконанні практичних завдань 3 дисциплін «Живопис», «Композиція», 3 пленерної практики, але і в самостійній творчій роботі, при розробці дипломних проектів і, звичайно ж, в подальшій професійній діяльності» [2, с. 280].

Формування професійних навиків неможливе без розвитку й тренування образного мислення, наявність якого більшість мистецтвознавців вважають обов'язковою ознакою кваліфікованого дизайнера. «Термін "образне мислення" відображає процес творчого пізнання у взаємозв'язку емоційно-чуттєвого, логічного та інтуїтивного» [3, c. 114].

Зважаючи на потреби сучасної методики викладання даної дисципліни, у Фаховому коледжі мистецтв та дизайну КНУТД впроваджено нові форми практичних занять. 
Структуру «Кольорознавства» складають дві частини. В першій частині фактично без змін був залишений програмний теоретичний курс 3 основними термінами, категоріями, правилами і вправами, на який студенти все одно мають спиратися в практичній діяльності, вивчають необхідні і базові поняття теорії кольору.

Друга ж частина - присвячена безпосередній творчій практиці, створенню художніх колористичних робіт. Причому перевага надається саме другій частині викладання предмету, тому що через практику, через послідовну постановку питань у зіткненні з конкретними проблемами теоретична частина засвоюється набагато ефективніше, втрачаючи «академічність» и набуваючи в очах студентів зв'язок з реальністю, а тому збуджуючи їхню цікавість.

При тому не заперечується певна ефективність «теоретичного» підходу до навчання. Але досвід показує, що практичний підхід загалом $є$ набагато більш ефективним як 3 точки зору засвоєння знань, так і з точки зору задоволення самих студентів навчанням.

Велику частину навчального часу займає вивчення типології гармонійних поєднань. «Недостатньо навчити студентів поняттю кольорового кола і навчити їх розрізняти відтінки, наступний етап - це гармонізація, вміння складати ці відтінки в гармонійні поєднання» [1, с. 49].

Перед початком створення художніх робіт студенти отримують від викладача попередню ввідну інформацію, що стосується їхнього завдання. Їм дається час на іï опрацювання, тобто на пошук доповнюючих та дотичних даних. Також цей етап включає продумування кожним зі студентів майбутньої роботи: іiі колористику, композицію, характер тощо - у відповідності до поставленого завдання та теми, що засвоюється в даний час.

Так, перше творче практичне заняття у дизайнерів зазвичай присвячено стилістиці Василя Кандінського. Це дозволяе продемонструвати глибокий взаємозв'язок між дизайном і мистецтвом XX століття. Василь Кандінський був одним із перших художників минулого століття, який вивів такі прості художні засоби, як колір чи форма, в якості головних «діючих осіб» художнього твору. Тому вивчення його теорії кольору - якнайкраще підходить для перших практичних занять, що полягають у створенні абстрактних композицій в стилістиці цього митця.

Для активного вивчення сили кольору за зразок беруться художникиавангардисти Марк Ротко та Джексон Поллок. В цьому завданні студентам пропонується створити композицію в абстрактноекспресіоністській стилістиці, лідерами якої були саме ці художники.

Для засвоєння фактурних властивостей поверхневого кольору студентам пропонується створити абстрактну композицію 3 
використанням фактурних паст, наповнювачів тощо. А при вивченні колористичної специфіки при роботі 3 об'ємними та динамічними формами - за приклад беруться твори відомого швейцарського художника та скульптора Жана Тенглі в стилі кінетичного мистецтва.

Одним із підсумкових завдань в курсі «Кольорознавства» $\epsilon$ комплексне завдання «Колористична інтерпретація вербального образу», при якому студенту пропонується обрати вислів, цитату чи поетичний уривок та передати його зміст за допомогою абстрактних площинних, об’ємних композицій, колажів. Це завдання активізує як інтелектуальні, так і чуттєві рецептори студента, коли необхідно знаходити компроміс між емоційним характером кольору, і колоритом, який би найглибше передавав смисл тексту. Це завдання сприяє розвитку образного мислення студентів різних напрямків дизайну - від архітектурного до графічного чи анімаційного. «Співставлення мови кольору з вербальною мовою в питаннях стилю та умовностей, норми та відхилень від неї виявляються плідними» [3, с. 110]. Колір не лише емоційно забарвлює сприйняття навколишнього світу, але й безпосередньо пов'язаний 3 надчутливим сприйняттям. Наприклад, Василій Кандинський свого часу вказував на зв'язок музики, текстів та кольору, розвиваючи науковий зміст поняття «синестезія». «Виходячи на рівень свідомості, смисл слова фіксується в кольорі, стає атрибутом емоційної оцінки» [3, с. 111].

Такі завдання дають можливість не тільки на практичному досвіді засвоювати принципи кольорознавства, але й вивчати історію сучасного живопису і дизайну у суто прикладному аспекті, фактично повторюючи етапи їхнього становлення власними руками. Набута таким чином теоретична інформація $\epsilon$ більш «ефективною» 3 точки зору засвоєння $\mathrm{i}$ можливостей професійного відтворення у майбутньому.

Далі - $\epsilon$ потреба у формуванні і підтримці колективної творчої атмосфери. Тому практичні заняття, як і теоретичні, є завжди груповими. Таким чином, студенти вчаться на практиці відпрацьовувати теоретичні знання, знаходити рішення безпосередньо в робочому процесі, швидко виправляти помилки; вони фактично вчаться в один в одного, порівнюючи роботи, аналізуючи процес, 3 одного боку навчаючись колективної роботи, а 3 другого вдаючись до позитивного творчого змагання. Під час такої роботи неодмінно проводяться дискусії, ставляться конкретні питання стосовно технології, прийомів, естетики та стилістики.

Викладач зі свого боку має змогу вчасно і доречно коментувати конкретний творчий процес, доповнюючи дії студентів новими теоретичними викладками, що акуратно накладаються на те, в чому вони приймають безпосередню участь. А через це створюються умови для 
максимальної відкритості студентів до спеціальних знань, їхнього максимального розуміння, до прояву більшої індивідуальності в роботах.

Як показав досвід, саме такий формат навчання ефективно сприяє засвоєнню теоретичних знань і грамотного їх застосування у подальшій професійній практиці, спокійному сприйняттю конструктивної критики, формуванню інтуїтивного відчуття естетики, «правильногонеправильного»; сприяє формуванню бажання створити естетичну роботу. Студенти починають усвідомлювати тонкощі творчої роботи, важливість пошукового етапу, щоденних тренувань.

Після таких занять важливо проводити підсумкові виставки студентських робіт 3 метою формування об'єктивного погляду на проведену роботу, дослідження реакції глядачів і самих студентів на проведену практику. «Складність оцінювання практичних робіт дисципліни «Кольорознавство» обумовлюється суб'єктивністю сприйняття кольору, незважаючи на існуючі правила і закони» $[1$, с. 48].

Наприкінці можна додати наступне. Студенти, працюючи в інтенсивних умовах творчого акту, в умовах активізації творчих i фізичних ресурсів підвищують ймовірність розкриття нових творчих можливостей, переходу на інший рівень образного та естетичного мислення, що є вкрай важливим для їхнього подальшого професійного становлення.

\section{Література:}

1. Давыдова Е. М., Куликова О. А. Критерии оценивания художественно-творческой деятельности студентов дисциплины «Цветоведение и колористика» / Межвузовская научно-методическая конференция «Преподавание графических дисциплин в современных условиях», 24 июня 2013 г. - С. 46-53.

2. Кадыйрова Л. Х., Мусина К. И. К вопросу о роли дисциплины «Цветоведение и колористика» в обучении будущих дизайнеров // Филология и культура. - 2015. - № 4 (42). - С. 279-282.

3. Сосипатрова О. В. Архитектурная колористика: развитие профессионального восприятия цвета в образном мышлении архитектора и дизайнера [Электронный ресурс]: учебно-практическое пособие. Волгоград: ВолгГАСУ, 2013. 